\title{
Framing Media Dalam Pembangunan Masyarakat Islam Di Kota Medan, Studi di Surat Kabar Harian Analisa Medan
}

\author{
Ahmad Nugraha Putra \\ Mahasiswa Pascasarjana UIN Sumatera Utara
}

\begin{abstract}
Abstrak
Penelitian ini membahas tentang bagaimana media massa khususnya surat kabar analisa Medan menggunakan Framing berita untuk pembangunan masyarakat dikota Medan. Wacana pembangunan masyarakat Islam dikota Medan tidak hanya dilakukan dengan pembangunan infrastruktur, namun juga menggunakan pendekatan penyajian berita serta konten-konten keislaman yang berguna untuk pembangunan masyarakat.
\end{abstract}

\section{Kata Kunci : Framing; Media; Masyarakat}

\section{PENDAHULUAN}

Media massa menjadi salah satu saluran bagi masyarakat untuk mendapatkan pemberitaan tentang hal-hal yang terjadi di sekitarnya. Konten media massa tidak dipungkiri dalam membentuk opini dan respon serta gerakan masyarakat terkait suatu fenomena. Untuk itu, kajian analisis framing menjadi penting dalam suatu mekanisme pemberitaan. Analisis jenis ini adalah salah satu model alternatif dalam menganalisis dan menungkap rahasia atau makna tersirat bahkan perbedaan dan pertentanan media dalam menyajikan suatu pemberitaan. Realitas yang dibingkai oleh media mungkin menjadi kalimat yang tepat terkait dengan pemahaman dasar analisis framing. Realitas sosial dipahami, di konstruksi dan dimaknai dengan bentukan dan makna tertentu. Inilah sesungguhnya yang dimaksud dengan realitas dalam tatanan sosial.

Media bertanggung jawab dalam membangun, menyajikan, menyuguhkan dan memproduksi suatu pemberitaan terkait fenomena dan peristiwa kepada pembacanya atau audiensnya. Namun, sebelumnya memberikan pemberitaan, umumnya media punya cara tersendiri dalam membingkai suatu pemberitaan yang syarat dengan cirri dan sikap media itu sendiri. Hal ini yang dikenal dengan istilah framing media. Seperti di Kota Medan, terdapat sejumlah media massa yang kredibel dan dijadikan sebagai sumber berita bagi masyarakat, salah satunya adalah Surat Kabar Harian Analisa yang berkedudukan di Jalan Jenderal Ahmad Yani Kecamatan Medan Kota, Kota Medan. Dalam tulisan ini, kita akan membahas bagaimana framing media, khususnya terkait sajian pemberitaan dengan konten-konten keislaman dalam upaya pembangunan masyarakat Islam di Kota Medan. Dalam kajian yang lebih luas dilihat dari halaman atau rubrik keislaman yang disajikan, kemudian dikaji tentang implikasi dan dampak yang dihasilkan dari konten tersebut terhadap pembangunan masyarakat Islam di Medan. 


\section{PEMBAHASAN}

\section{A. Analisis Framing Suatu Pengantar}

Framing Analysis merupakan metode dan cara analisis teks yang ada pada tatanan dan kategori penelitian pembangunan atau konstruksionis. Paradigma ini memandang realitas kehidupan sosial bukanlah realitas yang natural, melainkan hasil dari konstruksi bahkan berpotensi manipulasi dan pengaturan atau dibangun. Karenanya, konsentrasi analisis pada paradigma konstruksionis adalah menemukan bagaimana peristiwa atau realitas tersebut dikonstruksi, dengan cara apa konstruksi itu dibentuk atau dibangun (Eriyanto, 2002 : 43). Framing berhubungan dengan proses produksi berita dengan kerangka kerja dan aktivitas organisasi media. Bagaimana suatu peristiwa dapat dibingkai (di-frame) dan disajikan ke masyarakat, kita harus tahu, peristiwa dipahami dalam kerangka tertentu atau bingkai tertentu, tidak bingkai yang lain, bukan semata-mata disebabkan kecenderungan jurnalis, melainkan juga rutinitas kerja dan perusahaan media secara langsung atau tidak langsung mempengaruhi pemaknaan peristiwa atau dalam hal ini adalah sikap media.

Sadar atau tidak, masyarakat atau publik akan memerlukan parasigma alternatif yang kritis untuk mengungkapp realitas lain dalam wacana dan agenda media khususnya di media massa. Salah satunya metoe yang dipakai untuk itu yaitu dengan framing analysis. Analisis framing termasuk ke dalam paradigma kontruksionis. Paradigma ini memilik pandangan dan posisi tersendiri terhadap media dan sajian berita yang dihasilkannya. Pada dasarnya, dalam setiap pemberitaan, baik di media cetak, elektronik maupun media online dari suatu media memiliki frame tertentu. Untuk mengetahui bagaimana framing berita Harian Analisa terkait pembangunan masyarakat Islam di Kota Medan maka tulisan ini membahas tentang sajian pemberitaan keislaman yang terdapat dalam halaman keislaman yang dinamai halaman Mimbar Islam yang terbit setiap Jumat. Selain itu, kajian konten media akan menelaah sajian berita keislaman di halaman lain yang memuat konten keislaman.

Analisis framing sendiri adalah analisis yang memusatkan perhatian pada bagaimana media mengemas dan membingkai berita. Proses itu umumnya dilakukan dengan memilih peristiwa tertentu untuk diberitakan dan menekankan aspek tertentu dari peristiwa lewat bantuan tulisan, gambar, caption dan perangkat lainnya. Dalam tulisan ini, framing (framing analisis) di koten keislaman di Harian Analisa mengunakan bentuk analisis dari Zongdang Pan dan Gerald M. Kosicki. Model framing yang diperkenalkan oleh Pan dan Kosicki ini yaitu salah satu model paling banyak dipakai dan termasuk terpopuler. Dijelaskan analisis framing ini dapat menjadi salah satu alternatif dalam menganalisis teks media disamping analisis isi kuantitattif. Pandangan public terhadap suatu pemberitaan atau isu terhangat yang 
dibahas di suatu negara dapat dilekatkan dan dikonstruksikan dengan framing analysis lalu dapat dinegosiasikan. ${ }^{1}$

Framing atau membingkai dapat diartikan sebagai upaya dan proses menjadikan pesan atau konten media lebih menonjol, menempatkan kedudukan informasi lebih dari pada yang lain sehingga publik lebih tertuju pada pesan tersebut. Menurut Pan dan Kosicki, ada dua konsepsi dari framing yang saling berkaitan. Yaitu pertama dalam konsepsi psikologi. Framing dalam konsepsi ini lebih menekankan pada bagaimana orang mendapatkan konten media dan memproses informasi dalam dirinya. Kognitif juga berkaitan dengan framing termasuk proses dan strukturnya, bagaimana seseorang mengolah sejumlah informasi dan ditunjukkan dalam ritme terrtentu. Berikutnya yaitu konsepsi sosiologis. Pandangan ini lebih melihat pada bagaimana konstruksi sosial atas realitas. Frame yaitu proses seseorang mengkelompokkan, mengklasifikasikan, mengorganisasikan dan menafsirkan pengalaman agar mengerti dirinya dan realitas di luar dirinya. ${ }^{2}$

Dalam hal ini, wartawan atau jurnalis kadang bertindak sebagai pengatur atau pembangun pembingkaian di tengah masyarakat. Tapi selain wartawan, untuk menentukan tema atau penekanan suatu produk jurnalistik ada berbagai unsur yang terlibat di antaranya pihak keredaksian, narasumber maupun masyarakat sebagai pengguna itu sendiri. Misalnya dalam kerja jurnalis, ia berhak menetukan judul dan lead berita, struktur berita dan hal-hal lainnya. Wartawan bisa disebut sebagai petugas utama dalam menentukan tema atau tonjolan suatu pemberitaan. Sudut pandang konstruktivis, pembuatan berita seperti dijelaskan Gamson dan Modilgiani dikutip dalam bukunya Eriyanto "Analisis Framing", media mempunyai wacana yang dijelaskan sebagai suatu konsep kemasan yang interpretif. Lalu mampu memberikan makna dari suatu isu. Bagian-bagian berita tentu punya struktur internal yang bertujuan menjadikan gagasan yang mengorganisasikan atau mengatur suatu pembingkaian. Sehingga mampu mengerti kejadian atau peristiwa yang selaras dan relevan. Hingga pada tahap apakah suatu pemberitaan layak disampaikan kepada pengguna atau tidak.

Sementara, berita merupakan informasi yang layak disampaikan kepada publik, seperti informasi yang bersifat faktual, aktual, objektif, penting dan menarik perhatian publik. Sebuah berita yang disajikan kepada publik harus memiliki nilai berita yaitu acuan yang digunakan jurnalis yakni reporter dan editor untuk memutuskan isi berita yang memuaat fakta yang pantas dijadikan berita dan memilih mana yang lebih baik dan mana yang tidak disiarkan. Media massa menjadi perangkat sosialisasi sekunder yang berdampak penyebarannya paling luas dibanding

\footnotetext{
${ }^{1}$ Hajerimin. 2017. Analisis Framing Media Massa (Konstruksi Berita Politik Harian Amanah Tentang Abdul Aziz Qahhar Mudzakkar Jelang Pilgub Sul-Sel 2018 : Studi Analisis Framing Zongdang Pan dan Gerald M. Kosiki, Makassar : Skripsi Fakultas Usuhluddin, Filsafat dan Politik UIN Alauddin Makassar.

${ }^{2}$ Eriyanto. Analisis Framing: Konstruksi, Ideologi, dan Politik Media, Yogyakarta : LKiS. 2002 ) hal. 34
} 
agen sosialisasi lain. Meskipun dampak yang diberikan media massa tidak secara langsung terjadi, tapi begitu cukup siginikat dalam memengaruhi masyarakat, baik dari aspek kognisi, afeksi dan konatifnya. ${ }^{3}$

\section{B. Pengertian Analisis Framing}

Framing merupakan cara menjelaskan suatu peristiwa yang dikemas atau 'dipoles' sedemikian rupa dan disampaikan kepada masyarakat. Penyajian tersebut dilakukan dengan menekankan bagian tertentu, menonjolkan aspek tertentu dan membesarkan cara bercerita tertentu dari suatu realitas. Media menghubungkan dan menonjolkan peristiwa sehingga makna dari peristiwa tersebut lebih mudah diingat oleh khalayak. Karenanya, seperti yang dikatakan Frank D. Durham, framing membuat dunia lebih bisa diketahui dan bisa lebih dipahami. Realitas yang kompleks dipahami dan disederhanakan dalam kategori tertentu. Menurut pandangan subjektif, realitas sosial dapat menjelaskan suatu kondisi yang melted dan mudah berubah melalui interaksi manusia dalam kehidupan sehari-hari. ${ }^{4}$

Secara sederhana, analisis ini menggambarkan analisis mengetahui suatu realitas, meliputi suatu peristiwa, actor politik, kelompok atau hal lainnya yang dikemas media. Framing dilakukan tentu melalui tahap pembangunan terlebih dahulu. Realitas dalam teori ini dapat dimaknai dan dikonstruksi dengan maksud khusus. Menurut Erving Goffman secara sosiologis konsep frame analysis memelihara kelangsungan kebiasaan kita. Lalu mengklasifikasi, mengorganisasi dan menginterpretasi secara aktif pengalaman-pengalaman hidup kita untuk dapat memahaminya. Skema diinterpretasi dan itu disebut frames, yang memungkinkan individu dapat melokalisasi, merasakan, mengidentifikasi dan memberi label terhadap peristiwa-peristiwa serta informasi. ${ }^{5}$

\section{Lingkup Penggunaan Analisis Framing}

Anaisis framing memang tepat dipakai untuk melihat konteks-konteks sosialbudaya dalam suatu wacana media, khususnya terkait pemberitaan dan gagasan. Membangun, mempertahankan, mereproduksi, mengubah merupakan proses terciptakan suatu berita. Lalu dalam konten politik, analisis juga dpat digunakan. Terkait untuk melihat siapa mengendalikan siapa dalam suatu struktur kekuasaan, pihak mana yang diuntungkan dan dirugikan, kelompok yang bersama si penindas dan yang tidaktertindas, tindakan politik mana yang konstitusional dan

3 Mustika, Rieka. Analisis Framing Pemberitaan Media Online Mengenai Kasus Fedopilia di Akun Facebook, Jakarta : Puslitbang Aptika IKP Kementerian Komunikasi dan Informatika, Jurnal Penelitian Komunikasi, Vol. 20. 2017.

${ }^{4}$ Mulyana, Deddy. "Metodologi Penelitian Kualitatif", ( Bandung : PT Remaja Rosdakarya, 2006 ) hal. 57.

5 Ardina, Pratiwi. Konstruksi Realitas dan Media Massa, (Analisis Framing Pemberitaan LGBT di Republika dan BBC News Model Robert N. Entman), Yogyakarta : UIN Sunan Kalijaga, Jurnal Thaqafiyyat, Volume :19. 2018. 
inkunstitusional, kebijakan publik mana yang harus didukung dan tidak boleh didukung dan lainnya. Di Indonesia, media kaya dengan wacana namun hal ini berkaitan dengan kepentingan kekuasaan dan untuk kepentingan masyarakat atau komunitas. Dinilai perlu melihat realitas media massa dewasa ini, dalam mendapatkan informasi apapun begitu mudah dan kompleks. ${ }^{6}$

Kajian dengan analisis framing di Harian Analisa terkait dengan konten keislaman dalam rangka pembangunan masyarakat Islam. Penekanannya bagaimanya konstruksi media dalam memberitakan terkait konten islami. Dengan teknik dan metode bagaimana peristiwa ditekankan dan ditonjolkan. Hal ini bisa dalam pemberitaan ada bagian dihilangkan, luput, atau bahkan disembunyikan dalam pemberitaan. Analisis semacam ini tentu saja menggeser paradigma dalam kajian singkat ini. Sederhananya, analisis framing ini dalam diterapkan dalam semua sajian pemberitaan apapun jenis berita yang disajikan. Misal politik, budaya termasuk juga menyoal keagamaan. Atau dalam hal ini terkait dengan kajian pembangunan masyarakat Islam di Kota Medan melalui framing media di Harian Analisa. Melihat media massa yang telah ada lebih dari 40 tahun di Indonesia ini hingga menjadi salah satu media nasional yang dipertimbangkan tentu punya andil dalam menciptakan bentuk dan bingkai dari pemberitaan keislaman.

\section{Media Massa Dalam Pandangan Islam}

Dalam Islam, media massa bukan hanya menjadi tontonan tetapi sekaligus menjadi pedoman dan tuntunan. Oleh sebab itu, semua agama menjunjung tinggi kebebasan komunikasi dan informasi di antara umat manusia. Bahkan Allah SWT memerintahkan manusia selalu berkomunikasi dengan-Nya, memuji kebesaran-Nya, memohon ampunan-Nya, ridha-Nya, pertolongan-Nya, perlindungan-Nya, petunjukNya. Petunjuk yang menjadikan pengetahuan dari manusia menuju Tuhannya. Hal itu dapat disimpulkan, bahwa di ajaran Islam, media juga punya peran tersendiri, khususnya tentang hubungan kepada semua makhluk khususnya oran dengan gama lain namun tetap dengan nuansa kekeluagaan. Allah menjelaskan bahwa penyampaian pesan atau informasi kepada manusia melalui mahluk-mahluk yang dipilih-Nya untuk tugas komunikasi massa di dunia. ${ }^{7}$ Sebagaimana di terangkan dalam Q.S. Ibrahim/14:4 :

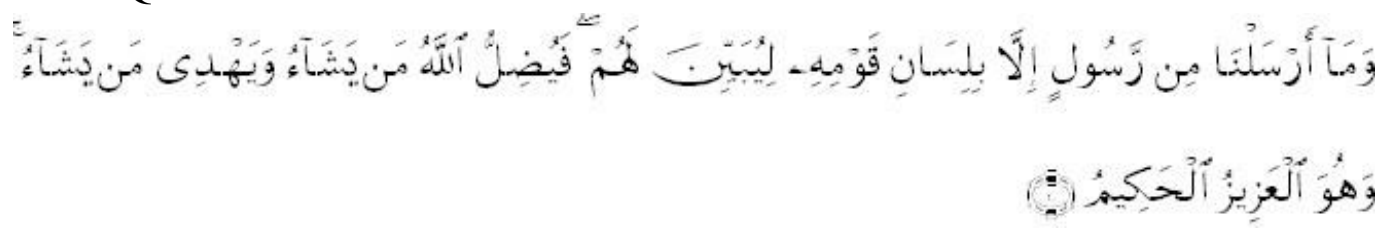

${ }^{6}$ Anggoto, Ayub Dwi, Media, Politik dan Kekuasan, Analisis Framing Model Robert N. Entman tentang pemberitaan hasil pemilihan Presiden, 9 Juli 2014 di TV One dan Metro TV, Ponorogo : Fakultas Ilmu Sosial dan Ilmu Politik Universitas Muhammadiyah Ponorogo, Jurnal Aristo Volume : 2. 2014.

${ }^{7}$ Muliadi, Komunikasi Islam, (Makassar : Alauddin University Press,2012), h. 61-62. 
Terjemahnya:

Kami tidak mengutus seorang rasulpun, melainkan dengan bahasa kaumnya, supaya ia dapat memberi penjelasan kepada mereka dengan jelas. Maka Allah menyesatkan siapa yang Dia kehendaki, dan memberi petunjuk, siapa yang dikehendaki, Dialah tuhan yang maha Kuasa lagiMaha Bijaksana.

Di dalam ayat tersebut kata billisani kaumihi dimaknai bilughatikaumihi yakni dengan memakai bahasa kaumnya. Maksud ayat tersebut adalah tidaklah Kami mengutus seorang rasul kepada suatu umat sebelum kamu, melainkan dengan bahasa kaumnya, agar dia dapat dengan mudah memahamkan perintah dan larangan-Nya kepada mereka. Kalau alqur'an yang dibawa oleh Rasulullah saw dengan bahasa mereka, maka kendala apakah yang menyebabkan sehingga tidak mau memahami dan mengkaji kandungannya, seperti berbagai hikmah dan hukum sehingga mereka memperoleh kebahagiaan di dunia dan akhirat. Demikian halnya dijelaskan dalam Q.S. Al-Hujurat/49:6 :

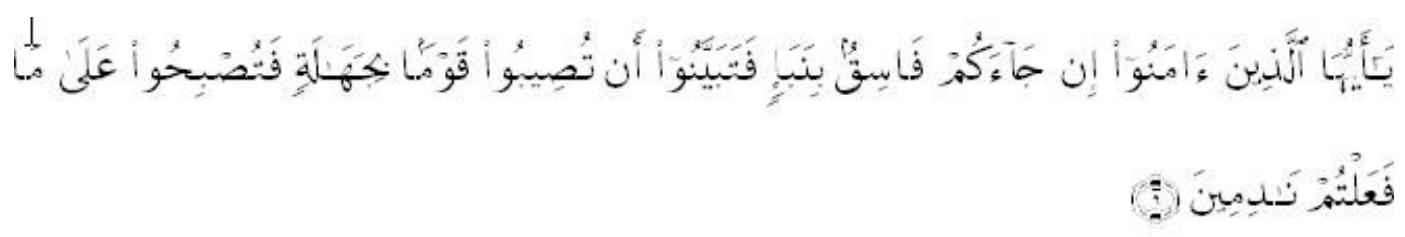

Terjemahnya :

Hai orang-orang yang beriman, jika datang kepadamu orang Fasik membawa suatu berita, Maka telitilah kebenarannya, agar kamu tidak mencelakakan suatu kaum karena kebodohan (kecerobohan), yang akhirnya kamu menyesali perbuatanmu itu. (Alquran terjemah)

Juga terdapat hadis yang menjadi dasar hukum komunikasi atau media massa dalam Islam.

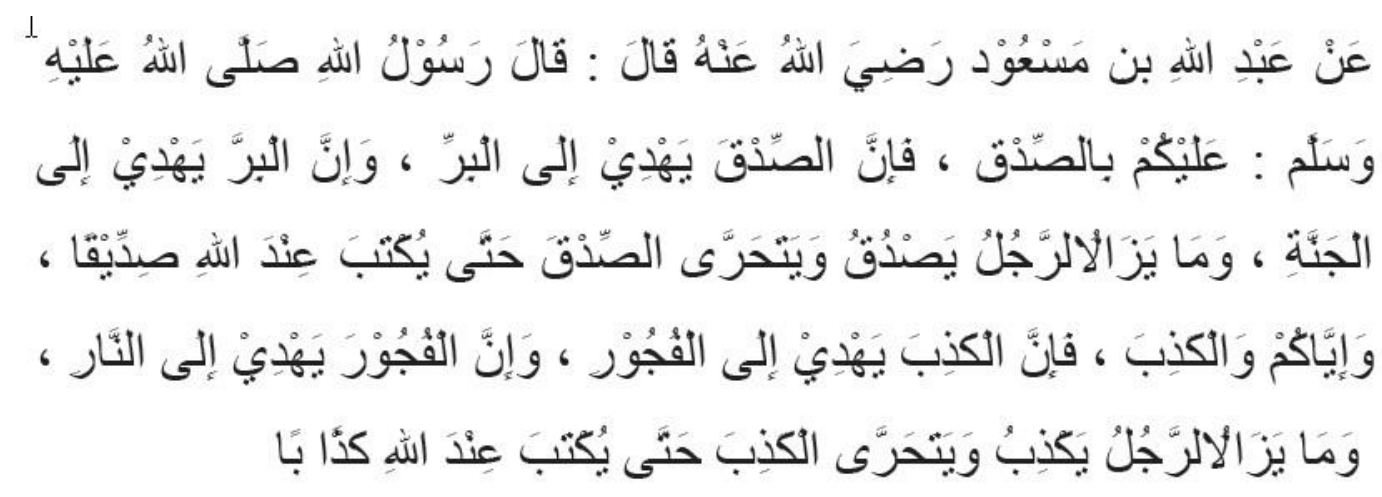

Terjemahnya :

Dari 'Abdullah bin Mas'ud Radhiyallahu anhu, ia berkata: "Rasulullah Shallallahu 'alaihi wa sallam bersabda, 'Hendaklah kalian berlaku jujur, karena sesungguhnya kebenaran (kejujuran) itu menuntun kepada kebaikan, dan kebaikan itu menuntun ke surga. Sesungguhnya seseorang itu (senantiasa) berlaku jujur 
sehingga dicatat oleh Allah swt. sebagai orang yang jujur. Dan jauhilah kebohongan itu karena kebohongan itu menuntun kepada kecurangan dan kecurangan itu menuntun ke neraka. Sesungguhnya seseorang itu (senantiasa) berlaku curang sehingga ia dicatat oleh Allah swt. sebagai orang yang curang. (HR. Al-Turmuzy). ${ }^{8}$

Dari berbagai penjelasan di atas, dapat disimpulkan bahwa media massa dalam memberikan pemberitaan haruslah berlandaskan kebenaran sesuai dengan nilai-nilai universal dari Islam itu sendiri. Hal ini juga sejalan dengan amanah Undang-undangan Pers Nomor 40 Tahun 1999 tentan pers yang harus menyajikan pemberitaan berdasarkan hati nurani dan menganut prinsip-prinsip kebenaran. Terkait sistem komunikasi sosial dengan sistem media massa, menurut ajaran Islam, ada juga yang disebut kebebasan komunikasi atau kebebasan media massa yang bertanggung jawab. Yang dimaksud bertanggung jawab adalah tanggung jawab kepada Allah SWT, seperti halnya dalam undang-undang tersebut.

\section{E. Fokus Bahasan Rumusan Masalah}

Fokus persoalan dalam tulisan ini yaitu analisis framing pada berita-berita keislaman di berbagai halaman di Harian Analisa Medan khususnya pada halaman Mimbar Islam yang terbit setiap Jumat dan mempunyai pembaca setianya serta pengisi atau kontributor. Atau dalam sajian keislaman lainnya di halaman Kota dan di halaman Opini. Untuk lebih fokus dan mendalam, bahasan di harian ini dibatasi pada terbitan sekitar Senin Desember hingga Jumat 6 Desember 2019. Sedangkan rumusan masalah dari bahasan ini karena menggunakan metode kualitatif dan studi dokumentasi serta interview, maka berdasarkan paparan di atas yaitu bagaimana framing media Harian Analisa terhadap berita-berita keislama, lalu sub bahasan yaitu:

1. Bagaimana pengemasan berita keislaman di Harian Analisa.

2. Bagaimana analisis framing dan analisis aenda setting berita-berita keislaman di Harian Analisa.

\section{F. Profil Harian Analisa Medan}

Analisa adalah sebuah surat kabar harian yang terbit di Medan. Surat kabar ini termasuk dalam Lumut Media oleh Lumut Communication. Kantor pusatnya terletak di Jalan Jenderal Ahmad Yani Nomor 35-49, Kesawan, Medan Barat, Medan, Sumatera Utara. Koran ini pertama kali terbit sejak pada 23 Maret 1972. Surat kabar ini slogan dan motto adalah Membangkitkan Partisipasi Rakyat Dalam Pembangunan. Surat kabar tersebut sekarang menjadi surat kabar dengan sirkulasi terbesar di Medan untuk berbagai bahasa Indonesia bersama Tribun Medan. Pada awalnya Analisa diterbitkan seminggu sekali sebelum menjadi surat kabar 85.

${ }^{8}$ Muh. Rusdi Thahir, HadisTarbawi I, (Makassar: Alauddin University Press, 2012), hlm. 
harian. Salah satu fitur Analisa yang paling terkenal adalah kartun Pak Tuntung yang muncul di halaman lima setiap harinya (kecuali Minggu) sejak 23 Maret 1973.

Analisa menempati kantor yang berada di Jalan Jenderal Ahmad Yani Nomor 35-49, Kesawan, Medan Barat, Medan. Saat ini harian Analisa dipimpin oleh Pemimpin Umum Supandi Kusuma dan Pemimpin Perusahaan Sujito Sukirman. Redaksional dipimpin wartawan kawakan eks-Lembaga Kantor Berita Nasional Antara yakni Pemimpin Redaksi H. Soffyan, didampingi Wakil Pemimpin Redaksi H. War Djamil. dan dibantu Sekretaris Redaksi Guntur Adi Sukma. Sebagai perusahaan pers yang puluhan tahun berdiri, juga tidak bisa menghindar dari kemajuan zaman dan teknologi. Termasuk perkembangan dunia informasi atau media berbasis internet juga ikut dikembangkan. Saat ini, tidak hanya industry media cetak atau koran yang dijalankan, tapi juga berkembang hingga media dengan platform daring yaitu dengan laman analisadaily.com, harian.analisadaily.com dan E paper - Harian Analisa. Juga merebak di media sosial yaitu Analisa di Facebook Analisa di Twitter dan Analisa di Instagram.

\section{Konten Internasional}

Seperti dijelaskan, media yang saat ini dinilai dengan oplah tertinggi di Sumut punya sajian informasi atau pemberitaan dengan skala internasional yang terbit di harian maupun mingguan. Rubrik atau halaman tersebut meliputi halaman utama, halaman Mancanegara, halaman Nasional, halaman Ekonomi dan Keuangan, halaman Opini, halaman Olahraga. Lalu terdapat rubrik mingguan seperti Komunitas, Cakrawala, Rebana, Rupa-rupa, Imaji, Gaya Hidup, Arsitektur, Seni, Pariwista, Hiburan, Gaya Otomotif, Lingkungan dan Teknologi.

\section{Konten Keislaman}

Dalam media yang dinilai masih menjadi nomor satu di Sumatera Utara ini dan sudah berdiri selama lebih dari 40 tahun serta masih eksis sampai sekarang, Harian Analisa mempunyai ruang khusus untuk pemberitaan keislaman. Dalam hal ini yaitu adanya halaman keislaman yang diberi nama Mimbar Islam yang terbit setiap Jumat. Konten ini memuat berbagai keislaman. Meliputi tulisan redaktur terkait yang temanya disesuaikan dengan isu atau hari besar Islam seperti Hari Raya Kurban, berpuasa dan lain sebagainya. Lalu terdapat sajian berita keislaman di luar itu. Yaitu terdapat di halaman Kota dan halaman Sumut yang memuat peristiwa keagamaan seperti peringataan hari besar Islam, acara zikir kelompok Islam tertentu dan lainnya. Konten keislaman kadang juga muncul di halaman opini, yaitu tulisan opimi atau artikel popular yang dikirimkan penulis luar yang membahas kajian keislaman. 


\section{HASIL PEMBAHASAN}

Seperti yang disampaikan di awal tulisan ini, bahwa setiap media manapun sejatinya mempunyai strategi tersendiri dan juga mempunyai bentuk kontruksi dalam pemberitaan. Hal yang dikenal dengan sikap media ini merupakan hal yang lazim dimiliki dan dijalankan setiap media. Termasuk di Harian Analisa Medan yang juga mempunyai konten keislaman di dalamnya bahkan disajikan khusus. Hal tersebut tentu merupakan produk jurnalistik yang dihasilkan dalam pemberitaan, sebagai media nasional yang berjaya dari Sumut, tentu memberikan sajian keislaman merupakan program dan juga permintaan dari masyarakat. Sajian tersebut, jika dilihat dari aspek produk jurnalistik tentuk menjadi menarik dan menjadikan media ini semakin ingin dibaca masyarakat karena sajian informasi yang diinginkan masyarakat khususnya tentang keislaman juga bisa didapatkan di sana.

Jika dikaitkan dengan komunikasi pembangunan dalam hal ini yaitu pembangunan masyarakat Islam melalui sajian media, maka Harian Analisa juga mempunyai framing untuk hal itu. Yang secara umum dapat dikategorikan pemberitaan keislaman yang moderat, berimbang, membawa kesejukan dan kedamaian hingga dirasa mewakili makna Islam yang sebenarnya di tengah masyarakat. Seperti diketahui, di Harian Analisa, sajian berita keislaman terdapat di halaman Mimbar Islam dan di berita-berita di halaman lain seperti di Kota, Sumut dan Opini. Untuk itu akan dijelaskan bagaimana analisis konten dan framing yang diberikan melalui konten tersebut.

Dalam halaman Mimbar Islam di Harian Analisa yang terbit setiap Jumat tersebut, terdapat pola dan bentuk sajian berita keislaman yang moderat dengan beberapa sajian yang konsisten di tiap edisinya. Pertama yaitu tulisan redaksional atau sikap media yang ditulis radaktur untuk Halaman Mimbar Islam itu. Tema tulisan disesuaikan dengan waktu penting dalam dunia Islam dalam setahun. Misal pada saat bulan puasa, maka tulisan terkait dengan Ramadan dan selanjutnya. Di dalamnya terdapat nilai-nilai moral dan nilai luhur keislaman lainnya yang ingin disampaikan ke pembaca. Selain itu, terdapat sedikitnya tiga tulisan artikel atau opini yang bermuatan keislaman ditulis oleh para penulis luar atau contributor untuk sajian halaman ini. Entah itu dari akademisi, praktisi dan mahasiswa akan disiarkan tulisannya melalui halaman ini. Secara umum, tulisan keislaman tersebut dimuat dengan bahasa yang santun dan mengedepankan nilai-nilai kebaikan, cinta damai, rukun dalam beberagaman, tidak provokatif sehingga sajian di halaman ini bisa dikatakan tulisan keislaman yang moderat namun tetap mengedepankan nilai-nilai dan aturan serta ajaran-ajaran Islam.

Lalu sajian di halaman Mimbar Islam lainnya yaitu selalu diisi dengan resensi buku. Yaitu dari buku-buku yang bernuansa Islam. Beberapa paragraf diberikan ruang untuk menjelaskan tentang suatu buku keislaman. Hal ini tentu merupakan upaya untuk mendukung karya penulis khususnya dan tentu untuk memajukan dalam rangka pembangunan masyarakat Islam. Melalui sajian ini, Harian Analisa dinilai 
turut ikut dalam pembangunan masyarakat dalam hal ini masyarakat Islam. Berbagai hal ini tentu sesuai dengan slogan media yang telah berdiri lebih 40 tahun ini yaitu 'Membangun partisipasi rakyat dalam pembangunan". Dari situ, dapat dijelaskan, tanpa memandang suku, agama dan ras, media Harian Analisa turut ikut dalam berkontribusi pada pembangunan peradaban dan masyarakat di dalamnya. Termasuk masyarakat Islam yang menjadi mayoritas di negara ini. Namun begitu tetap meninggalkan nilai dan esensi media nasional sebagai bagian dari bangsa yang beragam dan majemuk ini.

Selain sajian keislaman dalam halaman Mimbar Islam, berita keislaman juga bisa ditemui berbagai halaman di media ini. Seperti di halaman Kota, Sumut, Mancanegara, Opini dan lainnya. Menurut bahasan yang telah dilakukan berikut denan analisis konten, secara umum pemberitaan di halaman tersebut juga menganut aliran yang sama. Yaitu lebih mengutamakan kesejukan dan kedamaian dalam pemberitaan dan menghindarkan potensi-potensi konflik atau gesekan. Melihat, media melalui sajian-sajiannya bisa memicu berbagai respon di masyarakat. Untuk itulah, sikap media menjadi penting dan vital di industri media. Hal itu tentu juga untuk mencegah berbagai hal yang tidak diinginkan.

Intinya, pemberitaan keislaman lebih bersifat moderat dan menyajikan pesanpesan perdamaian di tengah masyarakat. Media besar ini dinilai lebih berhati-hati dalam memberikan pemberitaan yang akan punya kecenderungan negatif bagi masyarakat dan memilih untuk tidak menyiarkan jika terindikasi bisa membawa gesekan. Sementara hasil analisis konten yang lain dapat disimpulkan, sajian berita menurut kaidah jurnalistik sudah memenuhi ketentuan. Karena memang melihat media besar ini dinilai menjadi barometer media cetak yang kredibel dan punya kapasitas dan pengalaman yang tidak diragukan dalam mengemas berita. Terutama dalam menyajikan berita-berita yang keras bisa ditampikan lebih elegan dan tidak mengurangi nilai berita di dalamnya. Selain media tulis yang disajikan, produk jurnalistik di media ini juga dalam bentuk poto beserta captionnya. Terkait framing dalam pembangunan masyarakat Islam juga ditawarkan dengan nuansa kerukunan dan kedamaian dengan semua agama yang ada dan legal di Indonesia. Hal ini didapat dari berbagai poto lepas dengan konten keagamaan.

Bisa dikatakan, berbagai kontribusi media ini dalam menyajikan berita keislaman dalam upaya membangun masyarakat Islam di Kota Medan merupakan bentuk dari pelaksanaan dan optimalisasi fungsi media. Yaitu sebagai fungsi pendidikan atau edukasi. Kita ketahui pasti media dengan fungsi edukasi bisa menjadi asupan positif dalam memberikan literasi yang dapat mempengaruhi masyarakat, sehingga bisa menciptakan situasi pembangunan dan pengembangan sertta kemajuan di peradaban masyarakat Islam di Kota Medan pada khususnya. Hal ini yang juga dikenal dengan konsep atau gagasan yang dituangkan dalam yang namanya sikap media. Menurut informasi yang dihimpun di lapangan, sejak berdiri puluhan tahun, media ini tidak pernah menghadapi masalah misal terkait sanggahan 
pemberitaan dari konten keislaman yang disiarkan. Malah sebaliknya, banyak aktivitas Islam melalui berbagai organisasi yang turut dipublikaskan dan disebarkan serta dikabarkan kepada masyarakat melalui setiap lembaran-lembaran di tiap terbitan edisinya.

Maka, jika dikaitkan dengan analisis framing dan agenda setting media, maka di Harian Analisa ini dimilai berkontribusi positif dalam pembangunan masyarakat Islam di Kota Medan. Analisa dinilai masih menjadi pilihan masyarakat khususnya di Medan sebagai sumber berita dan refrensi kredibel dan terpercaya. Termasuk dan khususnya masyarakat Islam, bahwa dari media ini juga memberikan sajian berita dan konten-konten keislaman yang moderat juga turut ikut mempublikasi dan menyiarkan banyak aktivitas keislaman di Kota Medan baik yang digelar pemerintah setempat, organisasi Islam, mahasiswa dan lain sebagainya. Menurt analisis konten yang dilakukan pula, sajian berita keislaman di Harian Analisa ini begitu berhati-hati atas berita yang berpotensi menimbulkan negatif. Untuk itu, kontennya juga dikemas dengan baik dan lembut (soft) serta jauh dari pendekatan-pendekatan yang saat ini jadi isu hangat seperti radikalisme, ekstremisme hingga terorisme. Namun begitu pula, layaknya media professional, Analisa juga menjaga kualitas dari nilai berita yang disajiakan ke masyarakat.

Sebagai salah satu pilar penting di negara yang menganut demokrasi seperti di Indonesia, maka peran media juga terkait dengan framing yang diberikan tentu akan berpengaruh signifikan dalam membentuk opini publik, menggiring masyarakat hingga menghasilkan gerakan atau reaksi atau respon atas suatu pemberitaan yang diterima. Maka dalam pembangunan masyarakat Islam di Kota Medan, peran media sangat diperlukan untuk membantu dan mendukung percepata nilai-nilai serta ajaran Islam yang kaffah. Melalui framing yang diterapkan di Harian Analisa terkait pemberitaan keislaman juga dinilai dapat ditingkatkan dan dikuatkan untuk mendapatkan hasil atas pembangunan masyarakat yang lebih signifikan pula. 
Berikut beberapa tampilan dan sajian berita-berita keislaman di Harian Analisa:

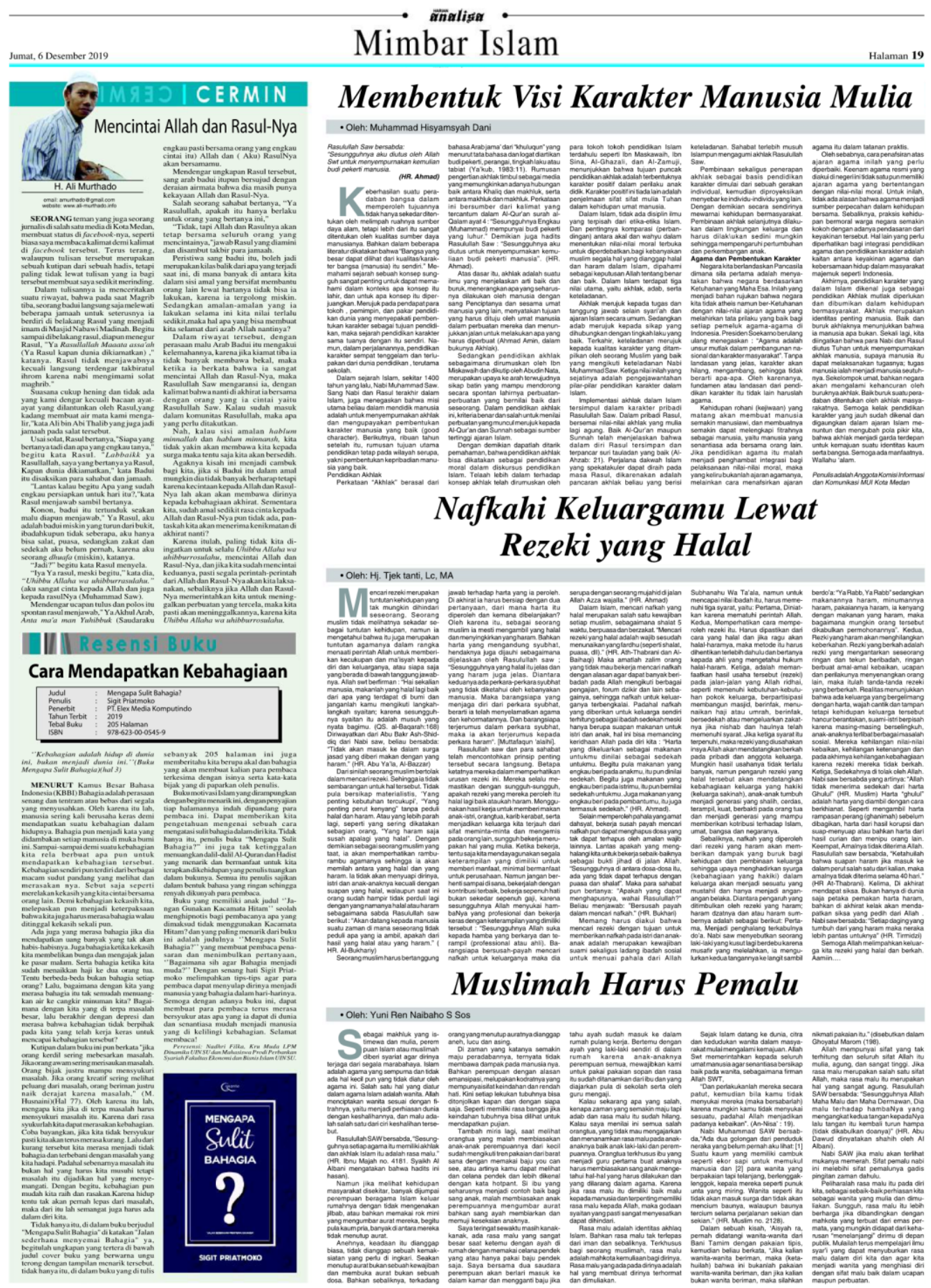

Gambar 1. Halaman Mimbar Islam Harian Analisa Edisi Jumat 6 Desember 2019 


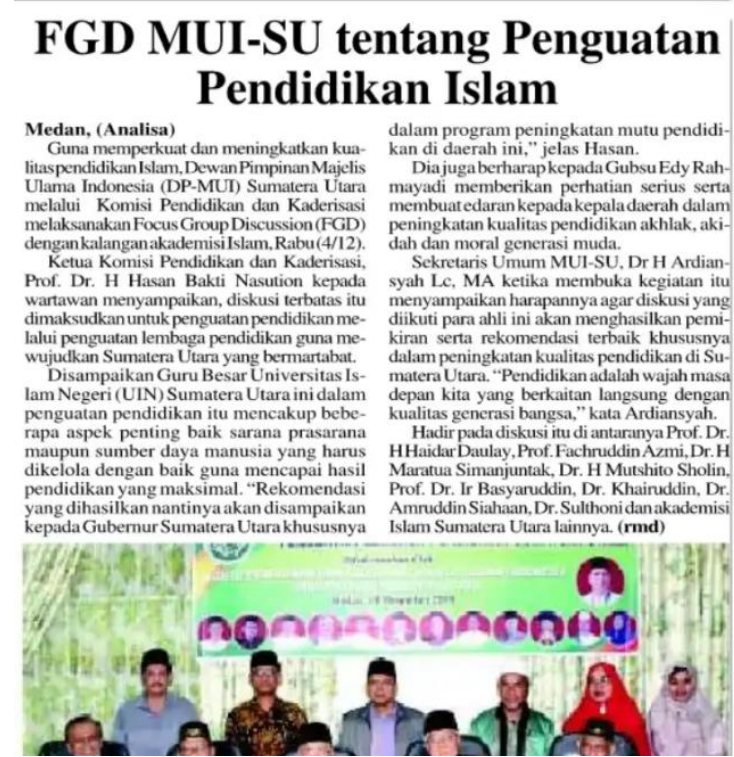

Pemuda Harus Memegang Teguh Ajaran Islam
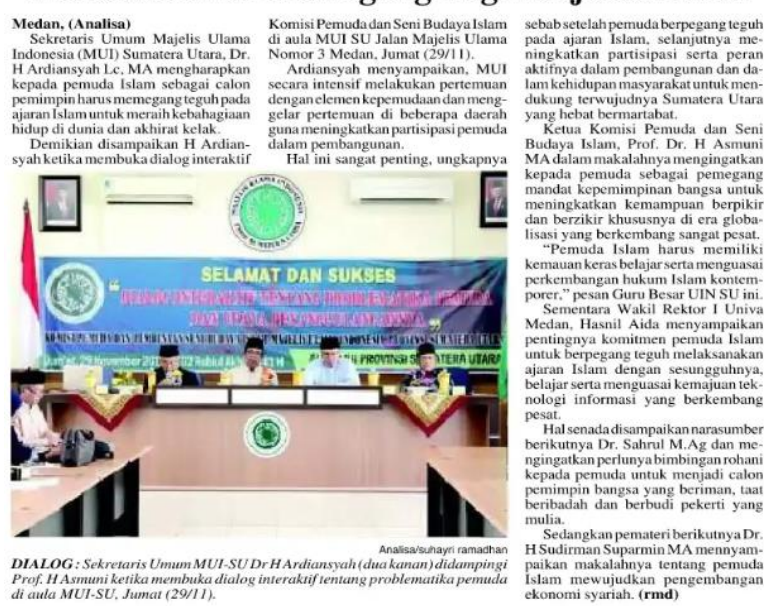

\section{Buya: Isi Hati dengan Zikir}

Medan, (Analisa)

Dalam diri manusia ada akal, jasad dan roh yang semuanya harus diberikan makanan sesuai dengan kebutuhannya. Jika tidak makan akan terjadi split of personality (kepincangan kepribadian).

"Makanan akal adalah membaca buku, mentafakuri ciptaan Allah, mentadaburi Alquran, berdiskusi dan belajar. Sedangkan makanan jasad adalah dengan memakan makanan yang halal dan thayyib, dan tidak hanya sekadar makan dan memakan segalanya, itulah yang membedakan manusia dan binatang, juga yang beriman," ujar Ketua Umum Majelis Zikir Tazkira Sumut, Buya KH Amiruddin MS, dalam pengajian, di Masjid Agung Medan, Minggu, (8/12).

Disebutkan Buya, bagi seorang yang beriman makanan yang halal dan thayyib adalah energi untuk mengerjakan amal-amal salih. Perut yang dipenuhi dengan makanan yang haram akan membuat pelakunya sulit mengerjakan kebaikan. Sedangkan makanan hati adalah zikir, istighfar, muhasabah yang menjadi sarana tazkiyatun nafs (penyucian jiwa).

Dikatakan, seseorang yang hanya diisi akalnya tetapi tidak ada iman di hatinya ,maka ilmu yang dia dapat bisa mendatangkan kemudaratan. Dari Ibrahim bin Maysaroh dari Anas dari Nabi SAW bersabda, "Siapa yang bertambah ilmunya tetapi tidak bertambah petunjuk, maka tidak bertambah baginya kecuali ia semakin jauh dari Allah."

"ZikirnyaNabiSAW dan para sahabat melahirkanmanusia yangmenangis di malam harikarenamenyesalidosa-dosanya danmemohonampun kepada Allah yang turun ke langit dunia di setiap sepertiga malam terakhir," kata Buya.

Lebih lanjut Buya menyebutkan, hati adalah tempat untuk merasa, sebagai sumber cahaya dari cahaya. Maka terus bersihkan hati dengan berzikir kepada Allah. "Kita hadir di majelis ini adalah untuk melatih berzikir kepada Allah, mulai dari zikir sir, zikir kalbu, dan zikir fuad. Sehingga zikir yang dilantunkan mempuyai rasa, yakni rasa takut kepadaAllah. Jikazikirkepada Allahsudah bersemayam dalam hati, maka hati akan memantulkan cahaya di atas cahaya (nur ala nur), dan berpengaruh kepada prilaku.

"Inti dari berzikir itu adalah untuk mendekatkan diri kepada Allah, maka isi hatimu dengan terus berzikir," ujar Buya KH Amiruddin MS.

Acara yang dipandu Ketua Tazkira Angkatan Muda Sumut, H Muhammad Duha Solihin SE, diawali dengan pembacaan ayat-ayat suci Alquran oleh Muhammad Syafii SSos, dilanjutkan dengan salat Tasbih, zikir, dan muhasabah dipandu Ustaz Muhammad Siddiq SAg. (sug)

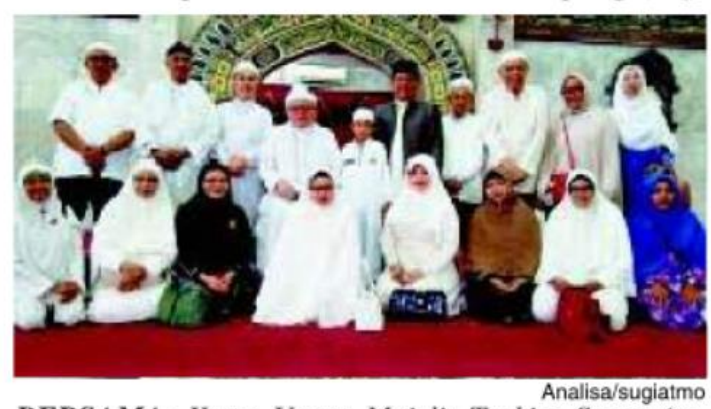

BERSAMA: Ketua Umum Majelis Tazkira Sumut (tengah) foto bersama perwakilan jemaah usai pengajian di Masjid Agung Medan, Minggu (8/12).

Gambar 2. Berbagai berita keislaman di berbagai halaman di Harian Analisa terbitan

Desember 2019 


\section{KESIMPULAN}

Framing media menjadi aspek penting setiap media dalam mengemas dan membingkat suatu pemberitaan yang disesuaikan dengan sikap media dan telah melewati berbagai tahapan yaitu melalui wartawan, narasumber, khalayak atau publik dan bahkan media itu sendiri. Seperti halnya Harian Analisa yang berkedudukan di Kota Medan juga menjalankan hal sama.

Jika dikaitkan dengan framing media dalam upaya pembangunan masyarakat Islam di Kota Medan, maka setelah melakukan berbagai bahasan disimpulkan bahwa Harian Analisa turut memberikan kontribusi positif dalam pembangunan masyarakat Islam Kota Medan khususnya melalui pemberitaan yang baik terkait keislaman sekaligus menjalankan serta mengoptimalkan fungsi edukasi dari media bagi masyarakat tentunya. Dalam hal ini, Analisa mampu menjadi salah satu sumber literasi bagi masyarakat Islam khususnya di Kota Medan terutama dalam pemberitaan dan penyiaran aktivitas serta kemajuan peradaban Islam Kota Medan.

Sajian dan konten keislaman dari Harian Analisa Medan ini dapat dilihat di halaman Mimbar Islam yang terbit setiap Jumat begitu pula dapat dilihat di berbagai halaman yakni halaman Kota, Sumut, Opini dan lain sebagainya. Namun begitu, kami memberikan saran agar pemberitaan keislaman di media ini bisa lebih dioptimalkan lagi dengan berbagai sajian dan program yang bernas sehingga pembangunan masyarakat muslim lebih cepat dilaksanakan. Juga menyarankan agar porsi atau kontribusi bagi para akademisi dan cendikia muslim juga lebih ditambahkan. Namun begitu, sajian framing keislaman dalam pemberitaan dinilai sudah baik, yaitu memberikan citra atau frame Islam yang universal, Islam yang moderat juga Islam yang cinta damai dan selaras dengan konsep kebangsaan, nasionalisme dan ideologi Pancasila yang merupakan suatu keniscayaan.

Menyingkap makna tersirat dari framing pemberitaan terkait konten keislaman di media ini, maka ditemukan upaya untuk menjaga persatuan dan partisipasi rakyat dalam pembangunan peradaban sebagaimana slogan Analisa.

\section{DAFTAR PUSTAKA}

Anggoto, Ayub Dwi. 2014, Media, Politik dan Kekuasan, Analisis Framing Model Robert N. Entman tentang pemberitaan hasil pemilihan Presiden, 9 Juli 2014 di TV One dan Metro TV, Ponorogo : Fakultas Ilmu Sosial dan Ilmu Politik Universitas Muhammadiyah Ponorogo, Jurnal Aristo Volume : 2.

Ardina, Pratiwi. 2018. Konstruksi Realitas dan Media Massa, (Analisis Framing Pemberitaan LGBT di Republika dan BBC News Model Robert N. Entman), Yogyakarta : UIN Sunan Kalijaga, Jurnal Thaqafiyyat, Volume :19.

Eriyanto. 2002. Analisis Framing: Konstruksi, Ideologi, dan Politik Media, Yogyakarta : LKiS.

Hajerimin. 2017. Analisis Framing Media Massa (Konstruksi Berita Politik Harian Amanah Tentang Abdul Aziz Qahhar Mudzakkar Jelang Pilgub Sul-Sel 2018 : 
Studi Analisis Framing Zongdang Pan dan Gerald M. Kosiki, Makassar : Skripsi Fakultas Usuhluddin, Filsafat dan Politik UIN Alauddin Makassar.

Kementerian Agama R.I. 2010. Al-Qur'an dan Terjemahannya, Hijaz: Terjemah Tafsir Perkata, Bandung : Sygma Creative Media Corp.

Muliadi. 2012, Komunikasi Islam, Makassar : Alauddin University Press.

Mulyana, Deddy. 2006. "Metodologi Penelitian Kualitatif”, Bandung : PT Remaja Rosdakarya.

Mustika, Rieka. 2017. Analisis Framing Pemberitaan Media Online Mengenai Kasus Fedopilia di Akun Facebook, Jakarta : Puslitbang Aptika IKP Kementerian Komunikasi dan Informatika, Jurnal Penelitian Komunikasi, Vol. 20.

Thahir, Muh. Rusdi Thahir. 2012. HadisTarbawi I, Makassar : Alauddin University Press. 